\title{
Research on Humanized Classroom Design in College English Teaching
}

\author{
Yu Yang \\ Jilin Agricultural University , China
}

Keywords: Humanized Classroom Design, College English, Teaching

\begin{abstract}
Humanized education is the development direction of Chinese educational reform and an important way to promote the comprehensive development of students' personality. Respect for the student's dominant position, pay attention to individual differences, individualized, appreciate and care for students are of great significance for the development of English education. Successful English teaching is inseparable from the careful classroom design, follow the contemporary college students to learn English thinking mode, in the English classroom teaching to establish "human" teaching philosophy can promote students, teachers, schools and common development, improve classroom teaching effect.
\end{abstract}

\section{Introduction}

The purpose of education is to cultivate talents. The development of education influences human development. At the same time, human development also promotes the development of education and even the world. Therefore, to build a vibrant, colorful world must improve the quality of life, enrich the human life and promote the perfect human and harmonious development. But our teaching is often one-sided emphasis on the teaching of knowledge and professional skills training, ignoring the humanistic quality of education, in the cultivation of human emotions, shaping the human mind, the development of human potential, improve the human personality is still far from doing well. Once the education left the people, left the human soul, left the spirit of the people cannot become a real education.

Czech educator Comenius once said: "The desire of children to learn is inspired by the teachers, if they are moderate, is the kind of good, do not rude way to make students alienate them, and with the kindness of feelings and words To attract them; if they treat their students kindly, they are easy to get the student's favor, the students would rather go to school rather than stay at home."In education, the object of education is people, people are diversified complex individuals, they have different personality, different characteristics, different ideas, in the teaching process to reflect their differences will be people-oriented, so that students of the body and mind Are devoted to learning up, so that they know what they want to know, which requires us to design in the teaching of students to individual differences, the heart needs as a prerequisite. So that our education for the full development of each student to provide services to enable their personality to healthy development.

In the 21st century, the college students 'personality development is becoming more and more obvious. Students' self-consciousness is more and more intense, and they hope to be respected and understood by others. In particular, they want to be respected and understood by teachers. To this end, teachers change the old educational philosophy and teaching methods are particularly important, but also an objective and urgent requirements. In the English classroom teaching, the establishment of "human" teaching philosophy, not only on the classroom teaching methods, means of optimizing the integration, but more mainly reflect the classroom "to the students" principle, to promote students, teachers, schools development of.

\section{The Modern Connotation of Humanized Education}

Humanized education, also known as "humanistic education", originated in the ancient Greek 
period Aristotle's "liberal education theory". Some Renaissance humanism thinkers believe that the purpose of education should be based on the comprehensive and perfect development of the individual, the core of education is mental training, rather than imparting vocational skills. Modern, Newman put forward the idea of humanistic education, that is, the purpose of university education is to train the mind, cultivate personal noble character and elegant taste. The rise of the knowledge economy in the world, "humanized education" as a worldwide trend of education, showing an irresistible trend, more and more educated leaders to accept and use the foresight, which means that education is being amended the original defects, to build the ideal life education theory, to the life education with the necessary humanistic care; is changing the traditional concept, out of the educational misunderstanding, to adapt to the new requirements of the new era; is to improve the comprehensive development of human services; Education and human happiness linked, and human freedom linked, and human dignity linked, and the ultimate value of people linked to education so that education is truly a human education rather than the education of the machine, so that education is not only people get Survival skills of a way, but also to enhance the level of people need to enrich the spiritual world of a way. "Therefore, in the final analysis, the essence of humanized education is to respect life and guide the healthy and healthy development of individual life. Its modern connotation is people-oriented and respects the intrinsic growth of the educated person. The core is the humanistic spirit. Each of the educated people is a living life individual, their value potential, role, behavior, motivation, demand, their emotional life and emotional experience, their moral life and personality development, etc. need to educate the reader to evaluate Understanding, respect, concern and satisfaction. Therefore, in the teaching process, the teacher should strive to create a pleasant learning atmosphere, so that each student's personality has been fully publicized, so that its enthusiasm and creativity to give full play to each student to get a respect, understand the feeling, but also full of sense of accomplishment, sense of value and happiness.

\section{The Abuse of Traditional College English Classroom}

Teachers regard the contents of the textbook as a golden rule, the teachings and tips as the irrefutable truth, the default lesson plans as a step by step guide. Classroom teaching is not created, no vitality, some just straightforward, mechanical labor, simple repetitive activities and some students only repeat and helpless.

Classroom teaching model is still followed by half a century ago Kailuo Fu five step teaching model (review the old knowledge, guide the new class, explain the new knowledge, contact the consolidation, the layout of homework). The specific teaching and management behavior in the classroom has long been a stereotypical, monotonous, constant pattern (sit, not interrupted, pre-class courtesy). Research shows that if a long time is only a pure form of expression, it gradually retains only its formal meaning, and its substantive things will be less and less.

Teaching goals, the knowledge and ability "a soft spot", the emotions, will, values, processes and methods do not pay enough attention, ignoring the comprehensive development is the ultimate goal of education, human psychological process is a complex whole, In the teaching organization form, since 1865, the capital of the same school after the introduction of class system, the primary and secondary schools in our dominant position in the classroom has been almost "seedling-style" in the classroom, geometric drawings and chairs arranged in a way, no matter how many people are lectures or discussion. In the role of the event, the classroom can only see, hear the voice of teachers and a small number of students, the lack of the majority of students really participate in the activities of the autonomy of students cannot give full play, the initiative is not fully reflected, independence Not implemented, creativity cannot be cultivated.

First, the classroom is not really effective exchanges and activities, the real interaction and interaction should be equal to start, the second is too concerned about the class of immobilized static knowledge, rarely involves the method of exploring knowledge. 


\section{The Definition of Humanized Classroom in College English Teaching}

Class is not a stage for students and teachers to perform, but the interaction between teachers and students, interactive stage. Teaching in the final analysis is a kind of communication behavior, only in the real effective interaction and interaction, the students get the knowledge is "internalized", and the growth of talent is "genuine", to develop the emotion is "true Really cut ".

The classroom is not a place for students to train, but to guide students to develop the place. Classroom students should be seen as a unique personality, fresh vitality of the individual, they have their own true feelings, have their own ability to judge right and wrong, with their own knowledge and experience has its own growth scene. Teachers do not want to instill knowledge from the outside, but from the inside to stimulate their curiosity, from the inside to guide students to understand the surrounding world, not from knowledge to students, but by the students to knowledge.

Classroom is not just a place to teach knowledge, but also a place to explore knowledge. Knowledge is the "noun", it is "verb", students through the initiative to explore, moving eyes, brain, moving mouth, hands to obtain knowledge is to master the most solid knowledge, is the most use of space and value of knowledge.

The classroom is not the place where the teacher's teaching behavior is modeled, but the place where the teacher's wisdom is fully demonstrated. The classroom is dynamic, it challenges the wisdom of teachers and teachers at any time according to the changing circumstances continue to adjust their behavior, according to their own grasp of the various information in the classroom, make judgments immediately take appropriate measures. To change the past monotonous teaching behavior, unified rigid strategy and to change the changing teaching model, give full play to their own wisdom, the students placed in the teaching of the starting point and the core position, should students move, according to the situation and change to learn to teach, so that the classroom full of vitality, showing the real vitality of life.

\section{The Implementation of Humanistic Classroom in College English Teaching}

Change the Teaching Model and Respect for the Student's Dominant Position. For a long time, due to the influence of traditional English teaching method, the teacher-centered "one-act" teaching model is deeply rooted, and the teacher's discourse hegemony in the classroom seriously weakened the students' chance of showing personality, leading students to lack the intervention of the topic, Get language experience, training and practice. As a result, teachers trained a batch of "dumb English" high talent, it is difficult to meet the needs of cooperation and communication, therefore, English teaching reform is imperative. The responsibility of the educator is to provide the educated with the external conditions for their growth and development and to give them appropriate guidance and assistance. This requires teachers to change the original teaching model or teaching methods as soon as possible, to establish a "student-centered" teaching new ideas, the focus of classroom teaching to strengthen the comprehensive ability of students to the fundamental goal. English is a very practical basic course, language skills to master and improve the individual students rely on the practice and the effectiveness of teaching depends largely on the subjective initiative and participation of students. Therefore, in the process of English teaching, we must adhere to the teacher-led, students as the main body, that is, to achieve the teacher fine, students practice, and teachers teach the scope of knowledge, depth, and timing according to the actual needs of students to adjust, so as to fully mobilize the enthusiasm of students to learn, so that a positive attitude, to maximize participation in classroom activities.

Recognize the Individual Differences in Students and Implement Individualized Teaching. Chinese vast territory, by the impact of the quality of education in various regions, students of English application ability is uneven, which largely affected the smooth conduct of English teaching, the specific performance: the basis of good students to accept the classroom information ability, They are often in the classroom speech interaction in the initiative, want to get more knowledge to 
enter; and poor foundation students "shame" to express themselves, often in a passive position. Over time, it will be "cold side, no one is interested." These phenomena require teachers to determine the teaching objectives, must be carefully analyzed to determine the starting point of the students in the teaching process to abandon the kind of uniform "one size fits all" teaching model, follow the classification guidance, individualized principles to adapt to personalized teaching The need. According to the characteristics of different stages of teaching, according to individual differences in teaching, according to different levels of standards and different personality characteristics to evaluate and educate students, to face up to the uniqueness of students, for students' personality characteristics, strengths and potential advantages of conscious Training and training, and actively for students to create the opportunity to show their talent, so that the individual life of the positive side of the full play, and strive to achieve the optimization of student case education behavior.

Establish the "People-Oriented" Thinking. The establishment of a harmonious relationship between teachers and students as early as two thousand years ago, I once said: "expensive to base, high as the base." In the teaching process, to deal with the relationship between teaching and learning, the establishment of a harmonious relationship between teachers and students is to improve the quality of teaching assurance. Teachers establish a "people-oriented" thinking, to the user's humane care, and strive to do strict and humble, wide and strict degree. Allow students to ask questions in the classroom, to discuss the issue, to allow students to have different views on the issue, more importantly, to allow students to make use of language errors. Because of the influence of Chinese and Western culture, customs, values and many other factors, there are many differences between English and Chinese language expression, for students, students in the understanding of language, the use of language, the inevitable language deviation The At this time, teachers should be patient guidance, not only cannot use the words of self-esteem students to evaluate students, but also to encourage students to encounter difficulties when the teacher or students for help.

Master the Skills of Appreciation. So that students have a sense of accomplishment. Appreciation education is an important way to realize the potential, to awaken self-confidence and stimulate creativity. It is an important way to realize modern education thought which is humanistic and humane. As a teacher to master the appreciation skills, pay attention to find the students "flash point" and timely encouragement, so that students' personality is fully publicized, so that the enthusiasm and creativity of students get full play. In the practice of English teaching, teachers often find a lot of excellent students, such as some students' rich knowledge, talking about foreign works familiar; some students spoken bad can speak with fluent English; and some students thinking Agility is a perfect partner in the classroom. For these excellent students, teachers tend to appreciate it, much praise, but at the same time teachers will find some "alternative", these students have mediocre grades, the classroom almost "Jinkou difficult to open", in fact, they are also appreciated The place.

\section{Conclusion}

Students are changing lives. Therefore, the English "human" classroom teaching is to meet the development of changing life. Continue to study the development of changes in the teaching object, improve the classroom teaching effect is the eternal theme of the teacher.

\section{References}

[1] Huifang Zhou: Science and Education, Vol. 6 (2004) No 53, p.25-26

[2] Hongli Zhang: Time Education, Vol. 12 (2005) No 27, p.74-76

[3] Qin Guo: Science and Education, Vol. 1 (2006) No 33, p.11-14

[4] Jieming Liu: Guangxi Normal University, Vol. 3 (2007) No33, p.121-124

[5] Jia Xinzhang, Li Jingyuan. Education, Vol. 6 (2014) No 53, p.25-26 